\title{
Vegetative anatomy of some Brazilian Zygopetalinae (Orchidaceae)
}

\author{
Cristiano Pedroso-de-Moraes', Thiago de Souza-Leal2 ${ }^{2}$, Fábio de Barros ${ }^{3} \&$ Maria das Graças Sajo $^{2}$ \\ 'Centro Universitário da Fundação Educacional Guaxupé. Av. Dona Floriana, 463, Centro, CEP 37800-000, Guaxupé, MG, Brasil. \\ cpmoraes@gmail.com \\ 2 Universidade Estadual Paulista. Instituto de Biologia. Departamento de Botânica, Rio Claro, Caixa Postal 199, 13506-900, \\ Rio Claro, SP, Brasil \\ Instituto de Botânica, Orquidário, Av. Miguel Stéfano, 3687, Água Funda, CEP 04301-902, São Paulo, SP, Brasil
}

Received on 19.V.2015

Accepted on 30.VII.2018

DOI 10.21826/2446-8231201873208

ABSTRACT - The anatomy of the vegetative organs of the Brazilian Zygopetalinae are poorly known. In the present paper we analyze the anatomy of roots, stems and leaves of twelve species, many of them of uncertain taxonomic position. We compare our results with those previously described for the same subtribe and some anatomical features, such as the number of velamen, root cortex and mesophyll layers, that can be useful in the systematic analysis of determined taxa, specially Dichaea Lindl., Promenaea Lindl. and Zygopetalum Hook. We also found features that can be interpreted as adaptations to drought, a situation that typically prevails in epiphytic environments where most of the species studied here live.

Keywords: Epidendroideae, Maxillarieae, orchid, vegetative habit

RESUMO - Anatomia vegetativa de algumas Zygopetalinae (Orchidaceae). A anatomia dos órgãos vegetativos de Zygopetalinae brasileiras é pouco conhecida. No presente estudo foram analisadas a anatomia de raízes, caules e folhas de doze espécies, muitas das quais apresentam posicionamento taxonômico incerto. Comparamos os resultados obtidos com os previamente descritos para a mesma subtribo e alguns caracteres anatômicos tais como: o número de camadas do velame, do córtex radicular e do mesofilo que podem ser úteis em análises sistemáticas de determinados taxa, especialmente em Dichaea Lindl., Promenaea Lindl. and Zygopetalum Hook. Também foram encontrados caracteres que podem ser interpretados como adaptações à escassez hídrica, uma situação que tipicamente prevalece em ambientes epifíticos onde a maioria das espécies estudadas habita.

Palavras-chave: Epidendroideae, Maxillarieae, orquídea, hábito vegetativo

\section{INTRODUCTION}

The Orchidaceae, with around 780 genera and 25,000 species (Soltis et al. 2005, Pridgeon et al. 2009), possesses a wide geographic distribution (Dressler 1981) with more than 2.000 species occurring in Brazil (Barros 1990, Dressler 2005, Campos 2008, Souza \& Lorenzi 2012). It is an easily recognizable group with strongly zygomorphic flowers in which perianth and reproductive elements are highly modified (Barros 1990, Dressler \& Chase 1995, Ruschi 1997, Pinheiro et al. 2004, Souza \& Lorenzi 2012). Within the family plants can be epiphytic, terrestrial or saprophytic and have sympodial or monopodial growth. Those with sympodial growth usually have a rhyzoma plus a straight axis with a single internode the heteroblastic type, or with more than one internode, the homoblastic type. Heteroblastic branches can be thickened forming pseudobulbs that store water and nutrients (Braga 1977, Williams 1979, Dressler 1981, Braga 1987, Campos 2008).

Leaves are simple, with or without distinction between blade and sheath, and displayed in a distichous or spiral phyllotaxy. They vary in shape and texture and are, in general dorsiventral although some representatives have ensiform or cylindrical blades (Schultz 1991, Souza \& Lorenzi 2012). Both epiphytic and terrestrial orchids possess specialized roots that absorb nutrients and store water. In general, the roots establish endomycorrhizal associations that improve their ability to absorb nutrients (Pridgeon 1986, Mauseth 2009, Souza \& Lorenzi 2012).

Some authors recognize three families of orchids (Dahlgren et al.1985) but molecular analyzes confirm the monophyly of the group and the occurrence of five subfamilies: Apostasioideae, Vanilloideae, Cypripedioideae, Orchidoideae and Epidendroidea (Chase et al. 2003).

The subtribe Zygopetalinae belongs to the subfamily Epidendroideae and comprises around 30 genera and 400 species of neotropical orchids with diverse vegetative and floral morphologies (Whitten et al.2005). It was traditionally included in the tribe Maxillarieae (Whitten et al.2005) but recent molecular analyses indicate that they form, together to Cymbidiinae, Eulophiinae, Bromheadiinae and Catasetinae, a monophyletic tribe: the Cymbidieae (Chase et al.2003).The circumscriptions of Zygopetalinae have been a matter of discussion (see Senghas \& Dietrich 1992; Dressler 1993; Szlachetko 1995) and the combined analysis of Whitten et al.(2005) recognized them as a 
monophyletic group that also includes the morphologically distinct genera Cryptarrhena (4 species) and Dichaea (111 species). Most Zygopetalinae are epiphytics, possess pseudobulbs and establish mutualistic relationships with mycorrhizal fungi (Dressler 1981). The pseudobulbs usually possess a single internode and the leaves vary on shape. The flowers, growing on lateral inflorescences, may or may not be resupinate, have a column of a variable size and four superposed pollinia (Dressler 1993, Whitten et al. 2005).

In an extensive study of Maxillarieae representatives, Stern et al. (2004) described the anatomy of the vegetative organs of many Zygopetalinae although no Brazilian species were included. In the present paper we describe the roots, stems and leaves of twelve Brazilian Zygopetalinae and compare the results with those of Stern et al. (2004).

\section{MATERIAL AND METHODS}

The material was collected from the living collection at the Instituto de Botânica de São Paulo (CO), according to the following specification: Dichaea pendula (Aubl.) Cogn. CO: 10448, 14816, 13461, Dichaea trulla Rchb. f. CO: 12875, 14815, 18144, Hoehneella gehrtiana (Hoehne) Ruschi CO: A1, Huntleya meleagris Lindl. CO: 17951, 18136, Koellensteinia tricolor (Lindl.) Rchb.f. CO: A1, Paradisanthus micranthus (Barb. Rodr.) Schltr. CO: VC1, VC2, Promenaea rollisonii (Rchb. f.) Lindl. CO: 10804, PR1, PR2, Promenaea xanthina Lindl. CO: VT1, VT2, VT3, Warczewiczella wailesiana (Lindl) E. Morren CO: 13620, 3184, Zygopetalum mackayi Hook CO: 16557; AOSP, Zygopetalum maxillare Lodd. CO: 1 Squeegee, Squeegee 2 and Zygopetalum pedicellatum (Sw.) Garay. CO: 16562.

For the anatomical analyses, the vegetative organs were fixed in 50\% FAA and preserved in $70 \%$ alcohol. The samples were free hand cut and the cross sections stained with $0.05 \%$ astra blue and safranin (Bukatsh 1972) and mounted in glycerin. For starch identification we used Lugol's solution (Bücherl 1962); for ligninin, Floroglucin plus Chloridric Acid (Jansen 1962); for lipids, Sudan III (Johansen 1940) and for flavonoids, Potassium Hydroxide (Costa 1982). The results were recorded with a digital camera coupled to an Olympus microscope (BX51 model).

\section{RESULTS}

\section{Root anatomy}

All roots (Figs. 1A-D) are cylindrical and possess a multilayered epidermis (velamen), a parenchymatous cortex and a vascular cylinder, although the organ diameter varies according to the species (Tabs.1,2).

In most of species, the tests indicated the presence of suberin and lignin in the velamen cells. The velamen is formed by 2-6 layers (Tab. 1) of elliptical or rectangular cells with varied secondary thickening in the walls, depending on the species. The cells of the velamen outer layer (epivelamen) are papilloses, in Dichaea trulla (Fig. 2A), and, in some other species, slightly smaller than those of the inner layers (Figs. 2B, C, Tabs. 1, 2). In the inner velamen layer (endovelamen), the isodiametric cells possess spirally thickened walls (Figs. 2B, C). In both Dichaea pendula (Fig. 2D) and Promenaea rollissonii there are fungal hyphae in the velamen. In the root cortex, the isodiametric exodermal cells have thickened walls in the outer periclinal surface, except for the passage cells that are without thickening (Figs. 1, 2A-D, Tab. 2).

Internally to the exodermis, the parenchymatous cortex is formed by a variable number of layers, according to the species (Figs. 1A-D, Tab. I). In this region, there are small intercellular spaces and the thin-walled cells are smaller close to the exodermis and to the endodermis layers (Figs. 1A- D).

Crystals of raphids are common in this region (Figs. 1A- D, Tab. 1) and fungal hyphae were observed in Zygopetalum mackayi, Paradisanthus micranthus and Promenaea xanthine (Figs. 1C, D). The endodermis is one layered and its cell walls have U-shaped thickening (anticlinal and inner periclinal walls) (Tab. 1), except for the passage cells, opposite the xylem poles, that are thinwalled (Fig. 2D).

The central cylinder is polyarch (Figs. 1A, D) with the number of protoxylem poles varying according to the species (Tab. 1). In the root center, the cells have with thickened walls in Hoehneella gehrtiana, Huntleya meleagris, Promenaea xanthina (Fig. 2E) and Warczewiczella wailesiana.

\section{Stem anatomy}

Sympodial growth predominates in the studied species, although in Zygopetalum pedicelatum it is monopodial. Dichaea pendula, Dichaea trulla and Z. pedicellatum (Figs. 3A-C) possess an aerial stem and Koellensteinia tricolor, Paradisanthus micranthus, Promenaea rollissonii, Promenaea xanthina, Zygopetalum mackayi and Zygopetalum maxillare a developed rhizome and pseudobulbs (Figs. 4A, B). In Hoehneella gehrtiana there is a rhizome and a reduced pseudobulb (Fig. 3D), and in Huntleya meleagris and Warczewiczella wailesiana (Figs. 4C, D) there are only rhizomes, from which tufts of leaves arise.

Both the pseudobulbs and the aerial stems (Figs. 5, 6) are covered by a single-layered epidermis of thin walled cells, plus a cuticle (Figs. 5A-D, 6A). In the aerial stem of D. trulla (Fig. 6B) and in the pseudobulbs of $P$. rollissonii, P. xanthina, Z. mackayi and Z. maxillare (Figs. 5A-D) the cuticle is slightly thickened.

The parechymatous cortex is narrow in the aerial stems and wide in the pseudobulbs (Figs. 5A-D, 6A, B). In the aerial stem of $D$. pendula there is not a clear morphological distinction between the cortical region and the vascular cylinder (Fig. 6A), but in those of D. trulla and $Z$. pedicellatum a ring of sclerified cells occurs in this limit. All pseudobulbs possess large parenchyma cells that store water and small parenchyma cells with amyloplasts (Figs. 5A, C, D). 

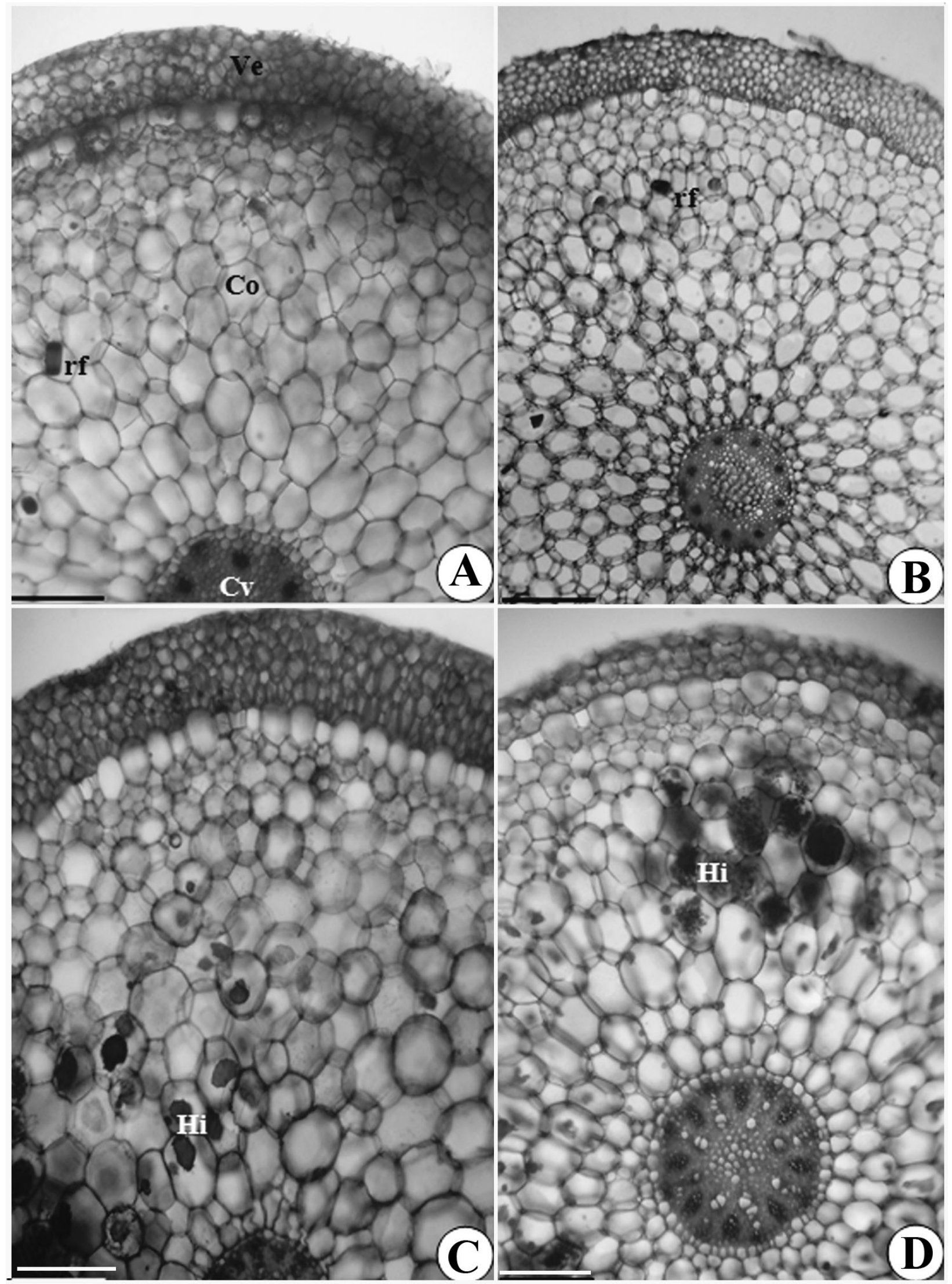

Figs. 1A-D. Cross-sections of roots showing the general structure. A. Hoehneela gehrtiana; B. Koellensteinia tricolor; C. Paradisanthus micranthus; D. Promenaea xanthina . ve $=$ velamen, $\mathrm{co}=$ cortex, $\mathrm{cv}=$ central cylinder, $\mathrm{Hi}=$ fungal hyphae, $\mathrm{rf}=$ raphids. Bars: Figs. $1 \mathbf{A}, \mathbf{C}, \mathbf{D}=50 \mu \mathrm{m} ; \mathbf{F i g} . \mathbf{1 B}$ $=200 \mu \mathrm{m}$. 
Table 1. Anatomical features of Zygopetalinae roots analyzed. $\mathrm{PC}=$ Papillary cell; $\mathrm{RC}=$ Reduced cell; $\mathrm{TE}=$ thickening in the external tangential wall; $\mathrm{U}=$ thickening $\mathrm{U}$.

\begin{tabular}{|c|c|c|c|c|c|c|c|c|c|c|}
\hline & $\begin{array}{l}\text { Overall } \\
\text { diameter } \\
(\mathrm{mm})\end{array}$ & $\begin{array}{c}\text { Velamen } \\
\text { diameter } \\
(\mathrm{mm})\end{array}$ & $\begin{array}{l}\text { Cortex } \\
\text { diameter } \\
(\mathrm{mm})\end{array}$ & $\begin{array}{c}\text { Vascular } \\
\text { cylinder } \\
\text { diameter } \\
(\mathrm{mm})\end{array}$ & \multicolumn{2}{|c|}{ Velamen } & Exoderm & Cortex & Endoderm & Protoxylem \\
\hline$\underline{\text { Species }}$ & & & & & $\begin{array}{c}\text { Cell layers } \\
\text { number }\end{array}$ & $\begin{array}{l}\text { Epivelamen } \\
\text { cells type }\end{array}$ & $\begin{array}{c}\text { Parietal } \\
\text { thickening } \\
\text { type }\end{array}$ & $\begin{array}{c}\text { Cell layers } \\
\text { number }\end{array}$ & $\begin{array}{c}\text { Parietal } \\
\text { thickening } \\
\text { type }\end{array}$ & $\begin{array}{l}\text { Poles } \\
\text { number }\end{array}$ \\
\hline Dichaea pendula & 0,08 & 0,015 & 0,04 & 0,025 & 3 & $\mathrm{PC}$ & $\mathrm{TE}$ & $6-7$ & $\mathrm{U}$ & 8 \\
\hline Dichaea trulla & 0,12 & 0,025 & 0,08 & 0,015 & 3 & $\mathrm{RC}$ & TE & $9-10$ & $\mathrm{U}$ & 7 \\
\hline Hoeneella gehrtiana & 0,4 & 0,02 & 0,37 & 0,01 & 5 & $\mathrm{RC}$ & $\mathrm{TE}$ & $10-13$ & $\mathrm{U}$ & 7 \\
\hline Huntleya meleagris & 0,4 & 0,03 & 0,35 & 0,02 & 4 & $\mathrm{RC}$ & $\mathrm{TE}$ & $10-13$ & $\mathrm{U}$ & 7 \\
\hline Koellensteinia tricolor & 0,5 & 0,05 & 0,42 & 0,03 & 6 & $\mathrm{PC}$ & $\mathrm{TE}$ & $10-13$ & $\mathrm{U}$ & 10 \\
\hline $\begin{array}{l}\text { Paradisanthus } \\
\text { micranthus }\end{array}$ & 0,6 & 0,05 & 0,5 & 0,05 & 6 & $\mathrm{RC}$ & $\mathrm{TE}$ & $12-15$ & $\mathrm{U}$ & 12 \\
\hline Promenaea rollisonii & 0,18 & 0,025 & 0,22 & 0,02 & 4 & $\mathrm{RC}$ & $\mathrm{TE}$ & $7-9$ & $\mathrm{U}$ & 7 \\
\hline Promenaea xanthina & 0,3 & 0,015 & 0,18 & 0,02 & 3 & $\mathrm{RC}$ & $\mathrm{TE}$ & $9-10$ & $\mathrm{U}$ & 7 \\
\hline $\begin{array}{l}\text { Warczewiczella } \\
\text { wailesiana }\end{array}$ & 0,6 & 0,02 & 0,4 & 0,18 & 4 & $\mathrm{RC}$ & $\mathrm{TE}$ & $6-7$ & $\mathrm{U}$ & 7 \\
\hline Zygopetalum mackayi & 0,4 & 0,03 & 0,35 & 0,02 & 4 & $\mathrm{RC}$ & $\mathrm{TE}$ & $10-13$ & $\mathrm{U}$ & 10 \\
\hline $\begin{array}{l}\text { Zygopetalum. } \\
\text { pedicellatum }\end{array}$ & 0,45 & 0,02 & 0,4 & 0,03 & 4 & $\mathrm{RC}$ & $\mathrm{TE}$ & $10-13$ & $\mathrm{U}$ & 10 \\
\hline
\end{tabular}

Table 2. Root traits of Zygopetalinae genres analyzed in this study and the Stern et al. (2004). PC = Papillary cell; $\mathrm{RC}=\mathrm{Reduced}$ cell; $\mathrm{TE}=$ thickening in the external tangential wall; $U=$ thickening $U ; n / a=$ notanalyzed.

\begin{tabular}{|c|c|c|c|c|c|c|c|c|c|c|}
\hline \multirow[b]{2}{*}{ Genus } & \multirow[b]{2}{*}{$\begin{array}{l}\text { Overall } \\
\text { diameter } \\
(\mathrm{mm})\end{array}$} & \multirow[b]{2}{*}{$\begin{array}{c}\text { Velamen } \\
\text { diameter } \\
(\mathrm{mm})\end{array}$} & \multirow[b]{2}{*}{$\begin{array}{l}\text { Cortex } \\
\text { diameter } \\
(\mathrm{mm})\end{array}$} & \multirow{2}{*}{$\begin{array}{l}\text { Vascular } \\
\text { cylinder } \\
\text { Diameter } \\
(\mathrm{mm})\end{array}$} & \multicolumn{2}{|c|}{ Velamen } & \multirow{2}{*}{$\begin{array}{c}\text { Exoderm } \\
\text { (Parietal } \\
\text { thickening } \\
\text { type) }\end{array}$} & \multirow{2}{*}{$\begin{array}{c}\text { Cortex } \\
\text { (Cells } \\
\text { layers } \\
\text { number) }\end{array}$} & \multirow{2}{*}{$\begin{array}{c}\text { Endoderm } \\
\text { (Parietal } \\
\text { Thickening } \\
\text { type) }\end{array}$} & \multirow{2}{*}{$\begin{array}{c}\text { Protoyilem } \\
\text { (Poles } \\
\text { number) }\end{array}$} \\
\hline & & & & & $\begin{array}{c}\text { (Cells } \\
\text { layers } \\
\text { number) }\end{array}$ & $\begin{array}{l}\text { (Epivelamen } \\
\text { type) }\end{array}$ & & & & \\
\hline \multicolumn{11}{|c|}{ This study } \\
\hline Dichaea & 0,1 & 0,02 & 0,06 & 0,02 & 3 & $\mathrm{RC} / \mathrm{PC}$ & $\mathrm{TE}$ & $4-9$ & $\mathrm{U}$ & $7-8$ \\
\hline Hoeneella & 0,4 & 0,02 & 0,37 & 0,01 & 5 & $\mathrm{RC}$ & TE & $10-13$ & $\mathrm{U}$ & 7 \\
\hline Huntleya & 0,4 & 0,03 & 0,35 & 0,02 & 4 & $\mathrm{RC}$ & TE & $10-13$ & $\mathrm{U}$ & 7 \\
\hline Koellensteinia & 0,5 & 0,05 & 0,42 & 0,03 & 6 & $\mathrm{PC}$ & $\mathrm{TE}$ & $10-13$ & $\mathrm{U}$ & 10 \\
\hline Paradisanthus & 0,6 & 0,05 & 0,5 & 0,05 & 6 & $\mathrm{RC}$ & $\mathrm{TE}$ & $12-15$ & $\mathrm{U}$ & 12 \\
\hline Promenaea & 0,24 & 0,02 & 0,2 & 0,02 & $3-4$ & $\mathrm{RC}$ & $\mathrm{TE}$ & $8-9$ & $\mathrm{U}$ & 7 \\
\hline Warczewiczella & 0,6 & 0,02 & 0,4 & 0,18 & 4 & $\mathrm{RC}$ & TE & $6-7$ & $\mathrm{U}$ & 7 \\
\hline Zygopetalum & 0,35 & 0,03 & 0,30 & 0,02 & $2-4$ & $\mathrm{RC}$ & TE & $10-13$ & $\mathrm{U}$ & $9-10$ \\
\hline
\end{tabular}

Stern et al. (2004)

\begin{tabular}{|c|c|c|c|c|c|c|c|c|c|c|}
\hline Dichaea & $\mathrm{n} / \mathrm{a}$ & $\mathrm{n} / \mathrm{a}$ & $\mathrm{n} / \mathrm{a}$ & $\mathrm{n} / \mathrm{a}$ & 4 & $\mathrm{n} / \mathrm{a}$ & $\mathrm{TE}$ & 5 & $\mathrm{U}$ & 6 \\
\hline Hoeneella & $\mathrm{n} / \mathrm{a}$ & $\mathrm{n} / \mathrm{a}$ & $\mathrm{n} / \mathrm{a}$ & $\mathrm{n} / \mathrm{a}$ & $\mathrm{n} / \mathrm{a}$ & $\mathrm{n} / \mathrm{a}$ & $\mathrm{n} / \mathrm{a}$ & $\mathrm{n} / \mathrm{a}$ & $\mathrm{n} / \mathrm{a}$ & $\mathrm{n} / \mathrm{a}$ \\
\hline Huntleya & $\mathrm{n} / \mathrm{a}$ & $\mathrm{n} / \mathrm{a}$ & $\mathrm{n} / \mathrm{a}$ & $\mathrm{n} / \mathrm{a}$ & 4 & $\mathrm{n} / \mathrm{a}$ & $\mathrm{TE}$ & 5 & $\mathrm{U}$ & 11 \\
\hline Koellensteinia & $\mathrm{n} / \mathrm{a}$ & $\mathrm{n} / \mathrm{a}$ & $\mathrm{n} / \mathrm{a}$ & $\mathrm{n} / \mathrm{a}$ & 5 & $\mathrm{n} / \mathrm{a}$ & $\mathrm{TE}$ & 6 & $\mathrm{U}$ & 11 \\
\hline Paradisanthus & $\mathrm{n} / \mathrm{a}$ & $\mathrm{n} / \mathrm{a}$ & $\mathrm{n} / \mathrm{a}$ & $\mathrm{n} / \mathrm{a}$ & 5 & $\mathrm{n} / \mathrm{a}$ & TE & 6 & Thin & 6 \\
\hline Promenaea & $\mathrm{n} / \mathrm{a}$ & $\mathrm{n} / \mathrm{a}$ & $\mathrm{n} / \mathrm{a}$ & $\mathrm{n} / \mathrm{a}$ & 4 & $\mathrm{n} / \mathrm{a}$ & $\mathrm{TE}$ & 5 & $\mathrm{U}$ & 9 \\
\hline Warczewiczella & $\mathrm{n} / \mathrm{a}$ & $\mathrm{n} / \mathrm{a}$ & $\mathrm{n} / \mathrm{a}$ & $\mathrm{n} / \mathrm{a}$ & $\mathrm{n} / \mathrm{a}$ & $\mathrm{n} / \mathrm{a}$ & $\mathrm{n} / \mathrm{a}$ & $\mathrm{n} / \mathrm{a}$ & $\mathrm{n} / \mathrm{a}$ & $\mathrm{n} / \mathrm{a}$ \\
\hline Zygopetalum & $\mathrm{n} / \mathrm{a}$ & $\mathrm{n} / \mathrm{a}$ & $\mathrm{n} / \mathrm{a}$ & $\mathrm{n} / \mathrm{a}$ & 4 & $\mathrm{n} / \mathrm{a}$ & $\mathrm{TE}$ & 5 & $\mathrm{U}$ & 10 \\
\hline
\end{tabular}

The vascular bundles are dispersed in the central region of the aerial stems (Figs. 6A-B) and are scattered in the pseudobulbs (Fig. 5B). The bundles are collateral and are surrounded by sclerified cells, exhibit caps of sclerified cells adjacent to the phloem and xylem or have several layers of sclerified cells surrounding the phloem (Figs. 5E-G). In the vascular bundles of the pseudobulbs of $H$. meleagris, $Z$. mackayi and Z. maxillare there are two layers of sclerified cells between the phloem and the xylem. Stegmatas, sclerified cells bearing spherical silica bodies 


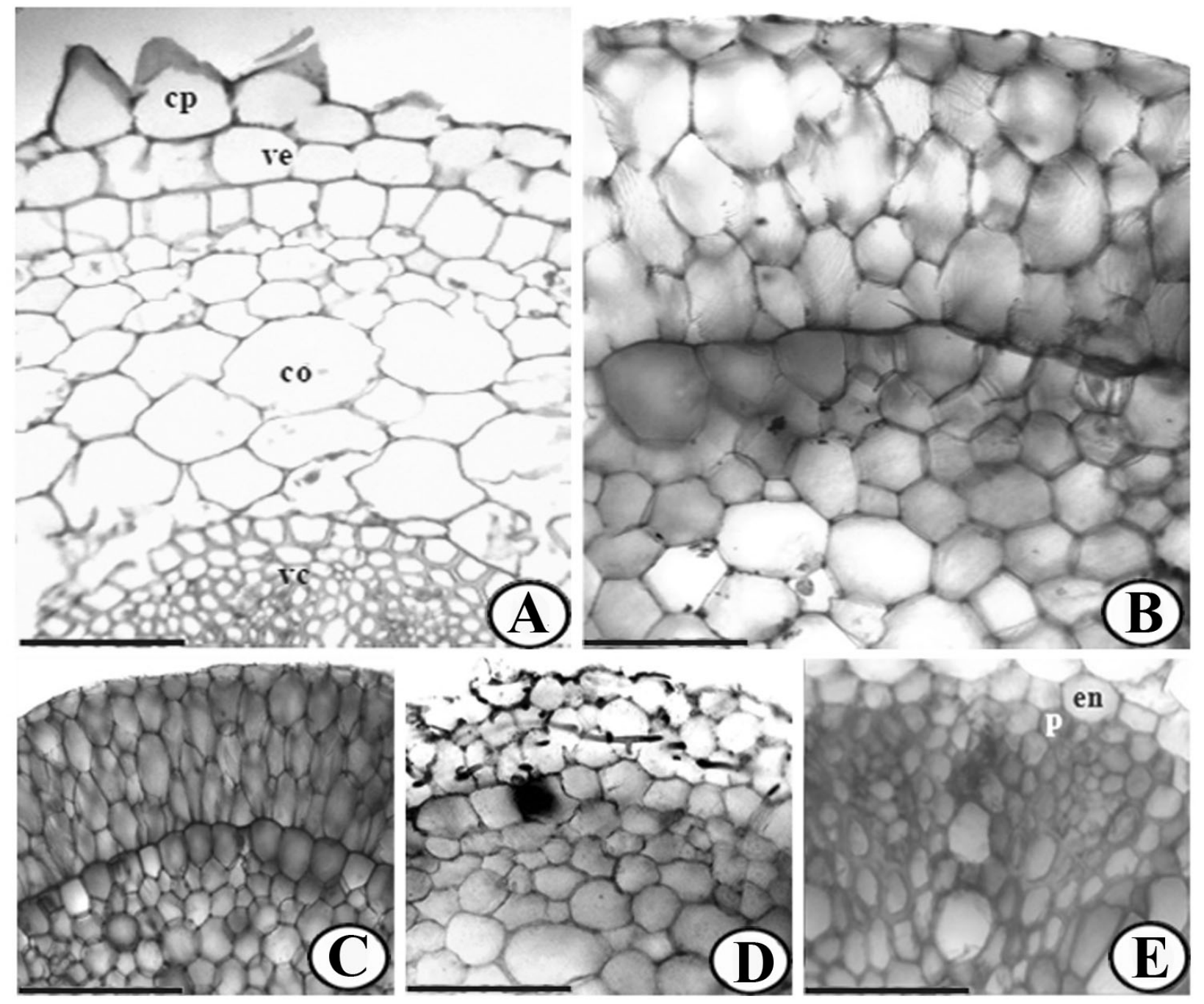

Figs. 2A-E. Cross-sections of roots showing velamen, exodermis and endodermis. A. Dichaea trulla.; B. Huntleya meleagris; C. Zygopetalum mackayi; D. Dichaea pendula $;$ E. Promenaea xanthina $. \mathrm{cp}=$ papillary cell, $\mathrm{co}=$ cortex, $\mathrm{vc}=$ vascular cylinder, en $=\mathrm{endoderm}, \mathrm{p}=\mathrm{periciclo}, \mathrm{ve}=$ velamen. Bars: Figs. A; D = $50 \mu \mathrm{m}$; Figs. B; C; $\mathbf{E}=100 \mu \mathrm{m}$.

(Fig. 5E), are commonly found in the periphery of the pseudobulb bundles (Tabs. 3, 4). Flavonoidic crystals occur in several pseudobulbs and in the aerial stem of $D$. trulla (Tab. 3) that also possesses starch grains (Tabs. 3, 4). Crystals of oxalate of calcium occur near the periphery of all pseudobulbs (Tab. 3).

The rhizomes are covered by a one-layered epidermis and a cuticle. The cortex, poor developed in relation to the central cylinder, is formed by small isodiametric cells (Figs. 6C-F). Raphides of oxalate of calcium are common in this region in all analyzed plants (Tab. 3). The central cylinder is composed by many vascular bundles, which possess several layers of sclerified cells adjacent to the phloem (Figs. 6C-F). Although the vascular bundles are clustered in the central region of the rhizomes, there is not a clear boundary between this region and the cortex, except for Z. maxillare that has 1-3 pericyclics cell layers of sclerified walls in this position (Fig. 6G). As observed for the pseudobulbs and the aerial stems, stegmata associated with vascular bundles are frequent in the rhizomes (Tab. 3). Crystals of flavonoids occur in the parenchymatous cells of most rhizomes (Tab. 3), and hyphae of fungus are frequent in the cortical region of $P$. xanthina and P. rollissonii.

\section{Leaf anatomy}

All the leaf mesophylls are narrow (Tab. 5) and irrigated by large and small vascular bundles (Figs. 7A-H). In Dichaea pendula and Hoehneella gehrtiana all the bundles are the same size. The leaves are covered by a continuous cuticle (Figs. 7B -C), with a thickness that varies according to the species (Tab. 5). The epidermal cells, of similar size on both faces, are rounded, rectangular, elliptical or polygonal in cross section. In Dichaea trulla the epidermal cells have a papillose appearance (Figs. 7B-C). All leaves are hypostomatic with the stomata situated on the same level as the other epidermal cells, or slightly projected, as in D. trulla (Fig. 7C). The stomata cells have thickened walls in the region between the guard cells, giving 

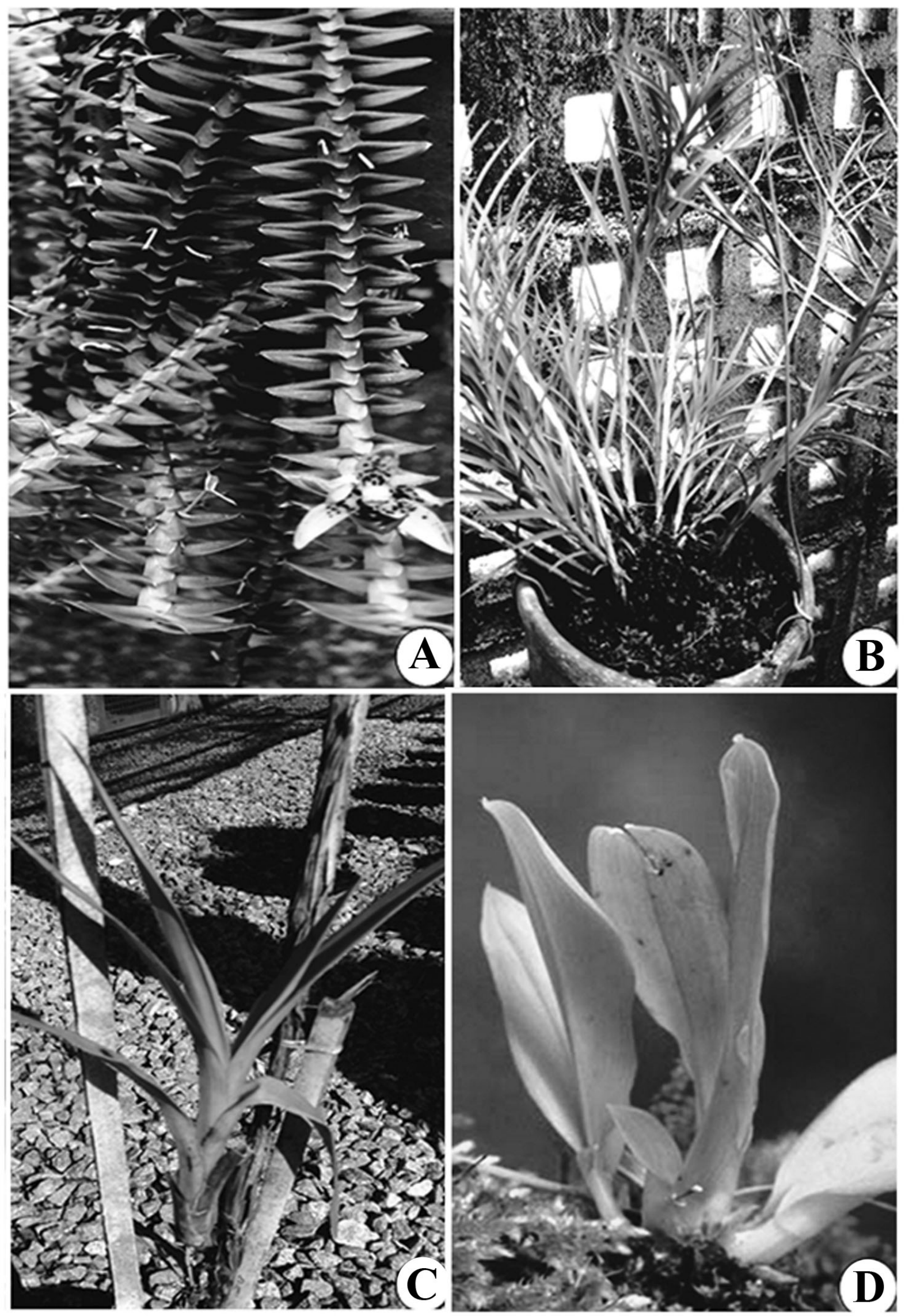

Figs. 3A-D. Growth habits. A. Dichaea pendula; B. Dichaea trulla; C. Zygopetalum pedicelatum; D. Hoehneella gehrtiana. 

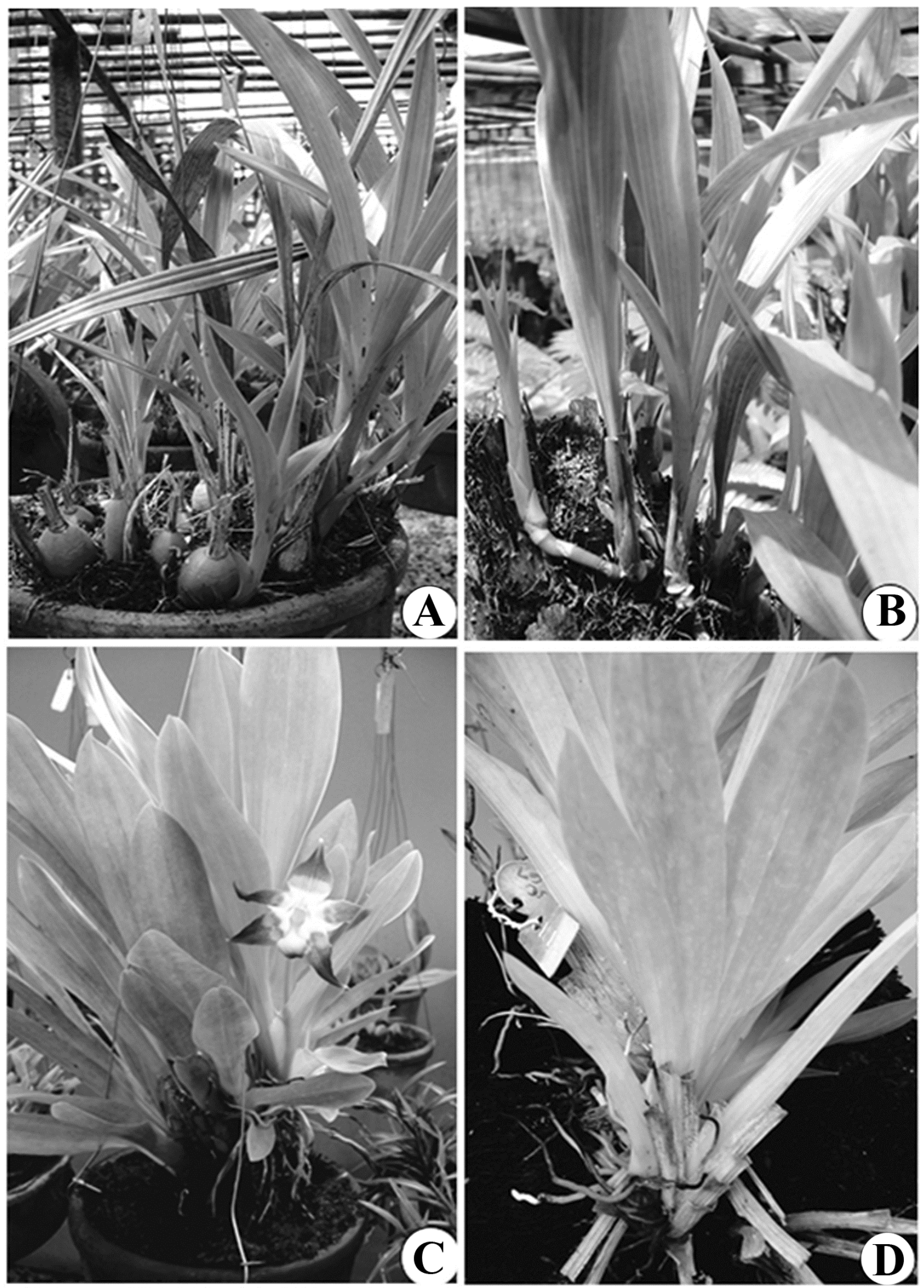

Figs. 4A-D. Growth habits. A. Zygopetalum mackayi; B. Zygopetalum maxillare; C. Huntleya meleagris; D. Warczewiczella wailesiana. . 


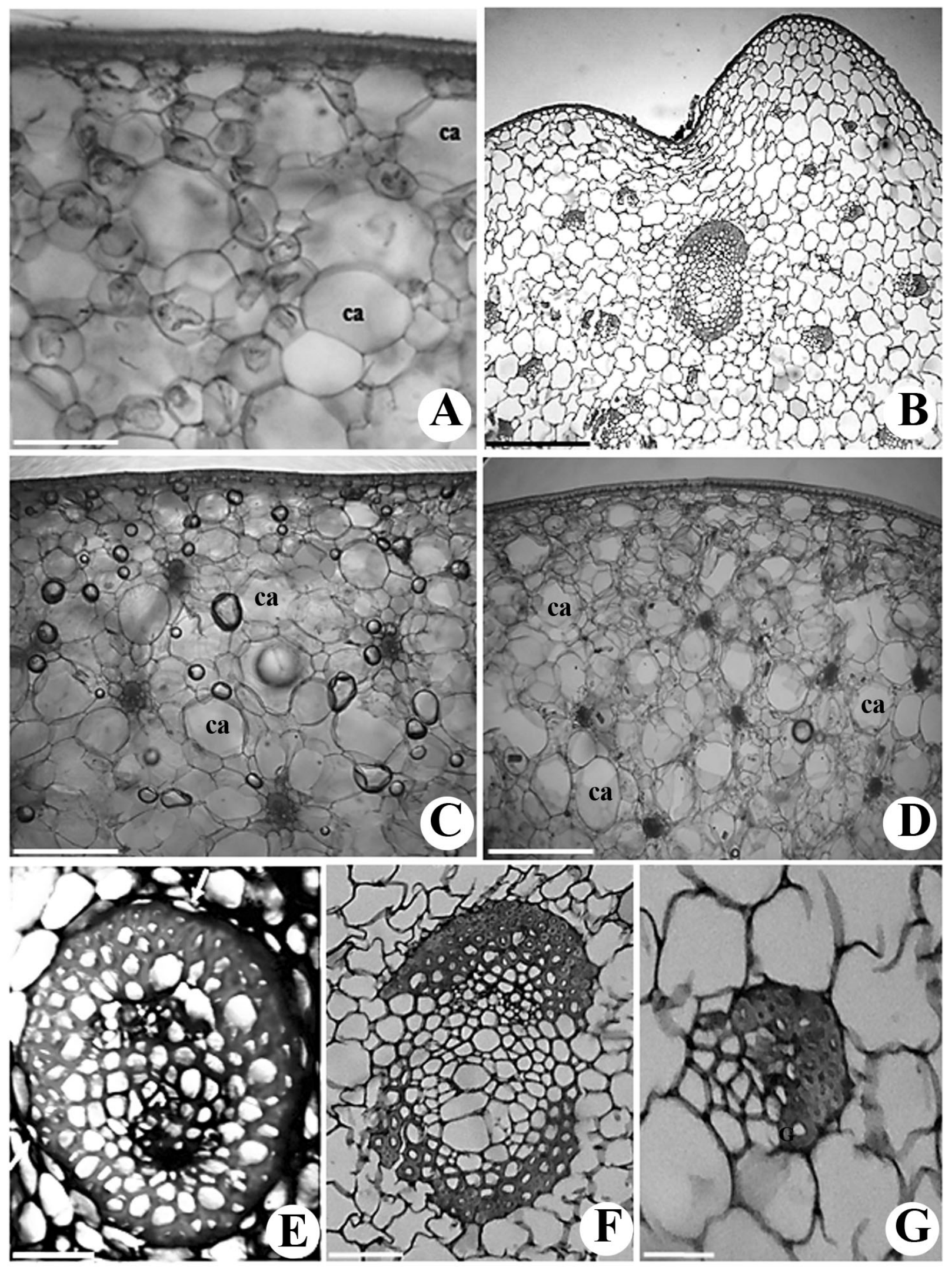

Figs. 5A-G. General cross-sections of pseudobulbs and disclosure of vascular bundles. A. Promenaea rollisonii; B. Promenaea xanthine; C. Zygopetalum mackayi; D. Zygopetalum maxillare; E. Huntleya meleagris; F. Promenaea xanthine; G. Paradisanthus micranthus. ca $=$ water storage cells, arrow = stegmata. Bars: Figs. A-G $=100 \mu \mathrm{m}$. 

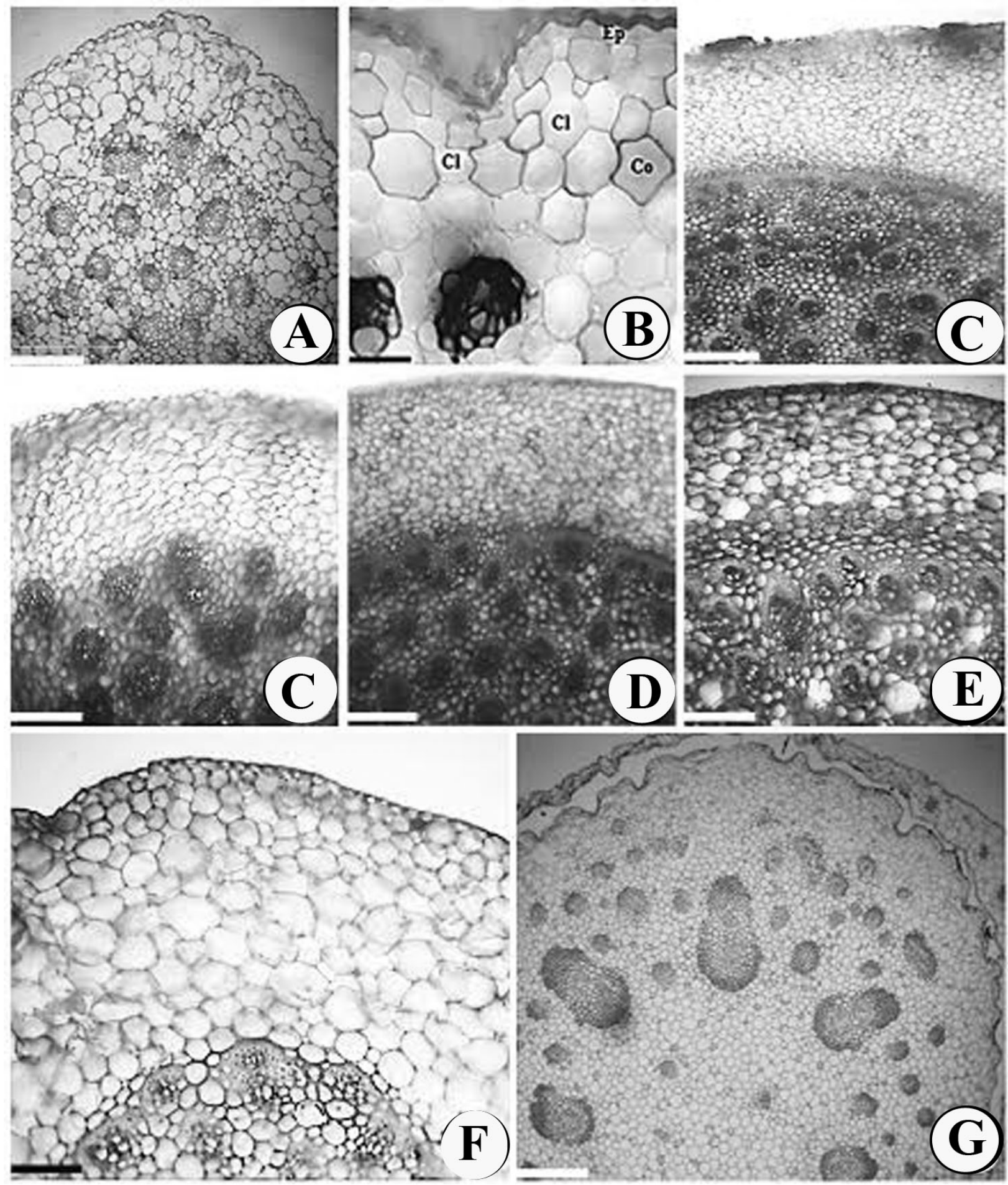

Figs 6A-G. Cross sections of aerial stems and rhizomes. A. Dichaea pendula; B. Dichaea trulla; C. Huntleya meleagris; D. Hoehneella gehrtiana; E. Promenaea rollissoniis; F. Zygopetalum mackayi; G. Zygopetalum maxillare. $\mathrm{cl}=$ claviform cells, co $=\mathrm{cortex}, \mathrm{p}=$ epidermis. Bars: Figs. A, B: $=50 \mu \mathrm{m}$; Figs. $\mathbf{C}-\mathbf{H}=100 \mu \mathrm{m}$.

a triangular appearance to the cell lumen. There are cuticular projections above the stomata opening forming a suprastomatal chamber. In some representatives (Tab. 5) there are 1-2 layers of large achlorophyllous subepidermal cells adaxially positioned forming a hypodermis (Figs. 7B, 8A). The mesophyll is not differentiated into palisade and spongy tissue and its cells are rounded or elliptical (Figs. 7I, 8A-F).
The vascular bundles are collateral and possess a cap of sclerified cells adjacent to the xylem and the phloem (Figs. 7A$\mathrm{B}, \mathrm{D}-\mathrm{H})$; the larger bundles may be surrounded by sclerified cells. The midrib possesses a single collateral bundle that, in most of species, is abaxially displaced and surrounded by sclerified cells (Figs. 7I, 8A-C). The midrib bundle occupies almost the entire leaf thickness in Koellensteinia 
Table 3. Features of analyzed stems in Zygopetalinae species. Epidermis: - = no evident thickening; $+=$ thickened.

Perivascular fibers: $+=$ around the vascular bundle; $\mathrm{Ph}=$ adjacent to the phloem. Crystals: $\mathrm{Fl}=$ flavonoidics; $\mathrm{Co}=\mathrm{Calcium}$ oxalate.

\begin{tabular}{ccccccc}
\hline \multirow{3}{*}{ Genus } & Epidermis & Cortex & & Perivascular & Starch \\
\cline { 2 - 5 } & Thickening & $\begin{array}{c}\text { Water storage } \\
\text { cells }\end{array}$ & Limitation & fibers & Crystals & Stegmatas \\
\hline
\end{tabular}

Aerial stems

Dichaea pendula

Dichaea trulla

Zygopetalum pedicellatum

Pseudobulbs

Hoeneella gehrtiana

Huntleya meleagris

Koellensteinia tricolor

Paradisanthus micranthus

Promenaea rollisonii

Promenaea xanthina

Zygopetalum mackayi

Zygopetalum maxillare

Rhizome

Hoeneella gehrtiana

Huntleya meleagris

Koellensteinia tricolor

Paradisanthus micranthus

Promenaea rollisonii

Promenaea xanthina

Warczewiczella wailesiana

Zygopetalum mackayi

Zygopetalum maxillare

-
+
+
-
-
-
-
+
+
+
+
-
-
-
-
-
-

-
+
+
+
+
+
+
+
+
+
+

-
-
-
-
-
-
-
-
-
-

+
+
+
+
+
-
$\mathrm{Ph}$
-
-
+
+
+
+
+
+
+
+
+
+
+
+
+
+
+
+
+
+
+
+
+
+
+
+
+
+
+
+
+
+

$\begin{array}{cc}\mathrm{Co} & - \\ \mathrm{Co}, \mathrm{Fl} & - \\ \mathrm{Co} & - \\ \mathrm{Co} & + \\ - & + \\ \mathrm{Co} & - \\ \mathrm{Co} & - \\ \mathrm{Co}, \mathrm{Fl} & + \\ \mathrm{Co}, \mathrm{Fl} & + \\ \mathrm{Co} & + \\ \mathrm{Co}, \mathrm{Fl} & + \\ \mathrm{Co} & + \\ \mathrm{Co}, \mathrm{Fl} & + \\ \mathrm{Co}, \mathrm{Fl} & + \\ \mathrm{Co}, \mathrm{Fl} & + \\ \mathrm{Co} & + \\ \mathrm{Co}, \mathrm{Fl} & + \\ \mathrm{Co}, \mathrm{Fl} & + \\ \mathrm{Co} & + \\ \mathrm{Co} & +\end{array}$

tricolor, Paradisanthus micranthus, Zygopetalum mackayi, Zygopetalum maxillare and Zygopetalum pedicellatum (Figs. 8D-F). Stegmata were observed in all leaves. Groups of fibers not associated with the vascular bundles, lying close to the abaxial surface, occur in the mesophyll of Huntleya meleagris and K. tricolor (Fig. 7H). Hyphae of fungus were observed close to the adaxial surface in several species (Tab. 5). In the mesophyll of D. trulla, $H$. gehrtiana and $K$. tricolor there are idioblasts with raphides and grains of starch are frequent in the mesophyll of Dichaea pendula, Hoehneella gehrtian, Warczewiczella wailesiana and Zygopetalum mackayi (Tab. 5).

\section{DISCUSSION}

\section{Roots}

As in other monocotyledons (Dahlgren \& Clifford 1982), a multilayered velamen of thin walled cells covers all the studied roots. The velamen is a specialized tissue that protects the root against heating and water loss (Pridgeon 1987) and that can also avoid the excessive water storage inside the organ (Gonzaga \& Gonzaga 1996). The occurrence of a velamen is associated with the epiphytic habit (Engard 1944, Dycus \& Knudson 1957), although this tissue can also occur in terrestrial orchids (Porembski \& Barthlott 1988, Stern et al.1993, Kurzweil et al.1995) and be absent in some representatives of the family (Singh 1986). Velamen with two, three and four layers as observed here (Tab.I) was also reported for the roots of most Zygopetalinae studied by Stern et al. (2004).

The velamen comprises an endovelamen and an epivelamen (Sanford \& Adanlawo 1973) that have the same origin as the intermediate layers and are formed by cells with no protoplast at maturity (Shushan 1974, Pridgeon 1987). In the roots of Hoehneella gerhtiana, Huntleya meleagris, Paradisanthus micranthus, Promenaea rollissonii, Warczewiczella wailesiana and Zygopetalum mackayi, the epivelamen cells are smaller than those of the endovelamen while in Dichaea pendula and Koellensteinia tricolor the epivelamen cells are papillose, a feature that possibly improves water absorption (Sanford \& Adanlawo 1973, Pridgeon 1987). The endovelamen cells are isodiametric and possess banded or striped thickening in the walls, depending on the species, as in others Zygopetalinae (Stern et al.2004). According to Benzing et al. (1983), the velamen cell walls are cellulosic with lignin and suberin impregnation that provides mechanical support and prevents cell collapsing during dry periods (Claus 1954). In most of roots studied here, the velamen cell walls are impregnated with suberin and lignin. However, as described for Dichaea bryophila (Oliveira \& Sajo 1999a) the lignin is absent in the root velamen of this genus (D. pendula and D. trulla). 
Table 4. Stem traits of Zygopetalinae genres analyzed in this study and the Stern et al. (2004). Epidermis: - = no evident thickening; $+=$ thickened. Perivasculares fibres: $+=$ around the vascular bundle; $\mathrm{Ph}=$ adjacent to the phloem; $\mathrm{n} / \mathrm{a}=$ not analyzed. $1-3=$ Occurrence in Dichaea trulla; $4=$ Stegmata not occur in Promenaea xanthina.

\begin{tabular}{lccccc} 
& $\underline{\text { Epidermis }}$ & $\underline{\text { Cortex }}$ & & Perivascular \\
\cline { 2 - 3 } Genus & Thickening & Water storage cells & Limitation & Starch grain & Stegmatas \\
\hline & & This study &
\end{tabular}

Aerial stems
Dichaea

Zygopetalum

Pseudobulbs

Hoeneella

Huntleya

Koellensteinia

Promenaea

Zygopetalum

Rhizome

Hoeneella

Huntleya

Koellensteinia

Paradisanthus

Promenaea

Warczewiczella

Zygopetalum
Paradisanthus

$\begin{array}{cc}-/+^{1} & -/+^{2} \\ + & + \\ & + \\ - & + \\ - & + \\ - & + \\ - & + \\ + & + \\ + & + \\ & - \\ - & - \\ - & - \\ - & - \\ - & - \\ - & - \\ - & - \\ - & -\end{array}$

This study

$-/+^{3}$
+
-
-
-
-
-
+
-
+
-
-
-

+
+
+
+
-
$\mathrm{Ph}$
-
+
+
+
+
+
+
+
+

Stern et al. (2004)

Aerial stems

Dichaea

Zygopetalum

Pseudobulbs

Hoeneella

Huntleya

Koellensteinia

Paradisanthus

Promenaea

Zygopetalum

Rhizome

Hoeneella

Huntleya

Koellensteinia

Paradisanthus

Promenaea

Warczewiczella

Zygopetalum
The outer layer of the cortex root, the exodermis, is formed by cells of tangentially thickened walls, as described for Dichaea bryophila (Oliveira \& Sajo 1999a). According to Haberlandt (1914), the velamen-exodermis set works as a system with the long suberized/lignified cells of the exodermis protecting the root cortex against desiccation and the thin-walled cells leading nutritive substances from the velamen to the cortical tissue. Specialized exodermis cells, named tilossomas or coverage cells that assist in the water condensation, frequently occur in the orchids roots (Pridgeon 1987). However, they seem to be absent in
Zygopetalinae as we did not find them in the species studied here, nor did Stern et al. (2004) in those they investigated.

Internally to the exodermis, the root parenchyma has many intercellular spaces and idioblasts containing raphides are common in this region, as in other Zygopetalinae (Stern et al.2004). Raphides are common in different organs of the Orchidaceae (Metcalfe 1963) and occur in many other monocots (Prychid \& Rudall 1999). The inner layer of the root cortex, the endodermis, is one-layered and formed by isodiametric cells with $U$ thickened walls, as described for other Zygopetalinae (Stern et al. 2004). 
Table 5. Environment, habit and anatomical features in analyzed Zygopetalinae. $+=$ presence, $-=$ absent, ct $=$ cuticle thickness $(\mu \mathrm{m})$, ae $=$ abaxial stomata with protected pore, $\mathrm{cs}=$ group of cells sclerified, wsc $=$ water storage cells, hyp $=$ hypodermis, steg $=$ sstegmata.

\begin{tabular}{|c|c|c|c|c|c|c|c|c|c|c|c|}
\hline \multirow{3}{*}{ Genus } & \multirow{2}{*}{\multicolumn{4}{|c|}{$\begin{array}{r}\text { Water storage features } \\
\text { Mesophyll }\end{array}$}} & \multicolumn{5}{|c|}{ Resistance to desiccation features } & \multirow{2}{*}{\multicolumn{2}{|c|}{$\begin{array}{c}\text { Special features } \\
\text { Mesophyll } \\
\end{array}$}} \\
\hline & & & & & \multirow{2}{*}{$\begin{array}{c}\text { Epidermis } \\
\text { ct }(\boldsymbol{\mu \mathbf { m }})\end{array}$} & \multicolumn{3}{|c|}{ Mesophyll } & \multirow[t]{2}{*}{ Fibers } & & \\
\hline & Epidermis & $\begin{array}{c}\text { Number of } \\
\text { layers }\end{array}$ & Hyp & $w s c$ & & $a e$ & $c s$ & Steg & & Hyphae & Starch \\
\hline Dichaea pendula & - & 5 & + & + & 36 & + & - & + & + & - & + \\
\hline Dichaea trulla & - & 5 & + & + & 712 & + & - & + & + & + & - \\
\hline Hoeneella gehrtiana & - & 8 & + & + & 36 & + & - & + & + & - & + \\
\hline Huntleya meleagris & - & 10 & + & + & 36 & + & - & + & + & - & - \\
\hline Koellensteinia tricolor & - & 5 & - & + & 36 & + & - & + & + & + & - \\
\hline Paradisanthus micranthus & - & 8 & - & + & 36 & + & + & + & + & - & - \\
\hline Promenaea rollisonii & - & 5 & - & + & 36 & + & + & + & + & - & - \\
\hline Promenaea xanthina & - & 5 & + & + & 36 & + & + & + & + & + & - \\
\hline Warczewiczella wailesiana & - & 12 & - & + & 712 & + & - & + & + & - & + \\
\hline Zygopetalum mackayi & - & 5 & - & + & 36 & + & - & + & + & + & + \\
\hline Zygopetalum maxillare & - & 7 & - & + & 712 & + & - & + & + & + & - \\
\hline Zygopetalum pedicellatum & - & 7 & - & + & 36 & + & + & + & + & - & - \\
\hline
\end{tabular}

Fungal hyphae were found in the root velamen of Dichaea trulla and Promenaea rollissonii and in the root cortex of Paradisanthus micranthus, Promenaea xanthina, Zygopetalum mackayi and Zygopetalum maxillare. Orchid roots frequently possess endomicorrizic hyphae that are usually established during seed germination and support development by assisting in the absorption of nutrients (Arditti 1967). Many orchids maintain this association throughout their lives while others become independent as adults (Arditti 1967, Sanford 1974). According to Sanford (1974), orchids depending on this association are partially saprophytes since the organic compounds are provided by the fungi either by diffusion or active transport.

Orchid roots have been classified into 12 types according to the presence or absence of an epivelamen, to the number of the velamen layers, to the shape of the cell wall thickening in the velamen and exodermis and to the organization of the cortex (Porembski \& Barthlott1988). All the Zygopetalinae studied here correspond to the Cymbidium type as they possess an epivelamen, an exodermis of outer thickened cell walls and a cortex of up eight layers. This root uniformity coincides with that described by Stern et al. (2004) for other Zygopetalinae.

Xylem and phloem are radially arranged. The xylem is polyarch and the root with the highest number of protoxylem poles (Paradisanthus micranthus, with 12) is of a larger diameter, while that with few poles (Dichaea pendula, with eight) has a reduced diameter (Tab. 1). Rütter \& Stern (1992) and Rosso (1966) described a close relationship between root diameter and the number of protoxylem poles, since this number varies in different roots of the same species, and in the same root, at different levels. The medulla is formed by thick-walled parenchyma cells, as in other Zygopetalinae (Stern et al. 2004).

\section{Aerial stem, rhizome and pseudobulb}

In many monocots, including the species studied here, growth originates in the rhizome which periodically gives rise to new stem branches and /or roots and pseudobulbs (enlarged stem segments where the leaves emerge). Rhizomes are thought to be restricted to plants with sympodial growth that can cover a large area of the substrate spreading indefinitely to achieve new sources of water and nutrients (Holttum 1955). All species studied here are of sympodial growth: Dichaea pendula and Dichaea trulla possess rhizomes and aerial stems and in Koellensteinia tricolor, Paradisanthus micranthus, Promenaea rollissoniis, Promenaea xanthina, Zygopetalum mackayi, Hoehneella gehrtianaand Zygopetalum maxillarethere are rhizomes and pseudobulbs. Warczewiczella wailesiana e Huntleya meleagris possess rhizomes from which spaced tufts of leaves arise.

Usually, the rhizomes and aerial stems are anatomically very similar being covered by a one-layered epidermis and possessing a parenchymatous cortex and many vascular bundles distributed in more than one ring in the central cylinder. This arrangement is common in the rhizomes of epiphytic Orchidaceae (Withner et al.1974), although in the terrestrial ones (Koellensteinia tricolor, Paradisanthus micranthus and Zygopetalum mackayi) the old part of the rhizomes epidermis is destroyed by friction with the substrate.

In both in the rhizomes and aerial stems there is not a clear morphological distinction between the cortex and the central cylinder, except for the aerial stem of Dichaea trulla and the rhizome of Zygopetalum maxillare, that have a pericyclic ring of sclerified cells in this region, as reported for some Pleurothallidinae (Pridgeon \& Williams 1979, Pridgeon 1982, Scatena \& Nunes 1996) and for representatives of the subfamily Cypriipedioideae (Rosso 1966). In general, at the boundary zone there is a higher concentration of vascular bundles without the presence of a differentiated endodermis. 


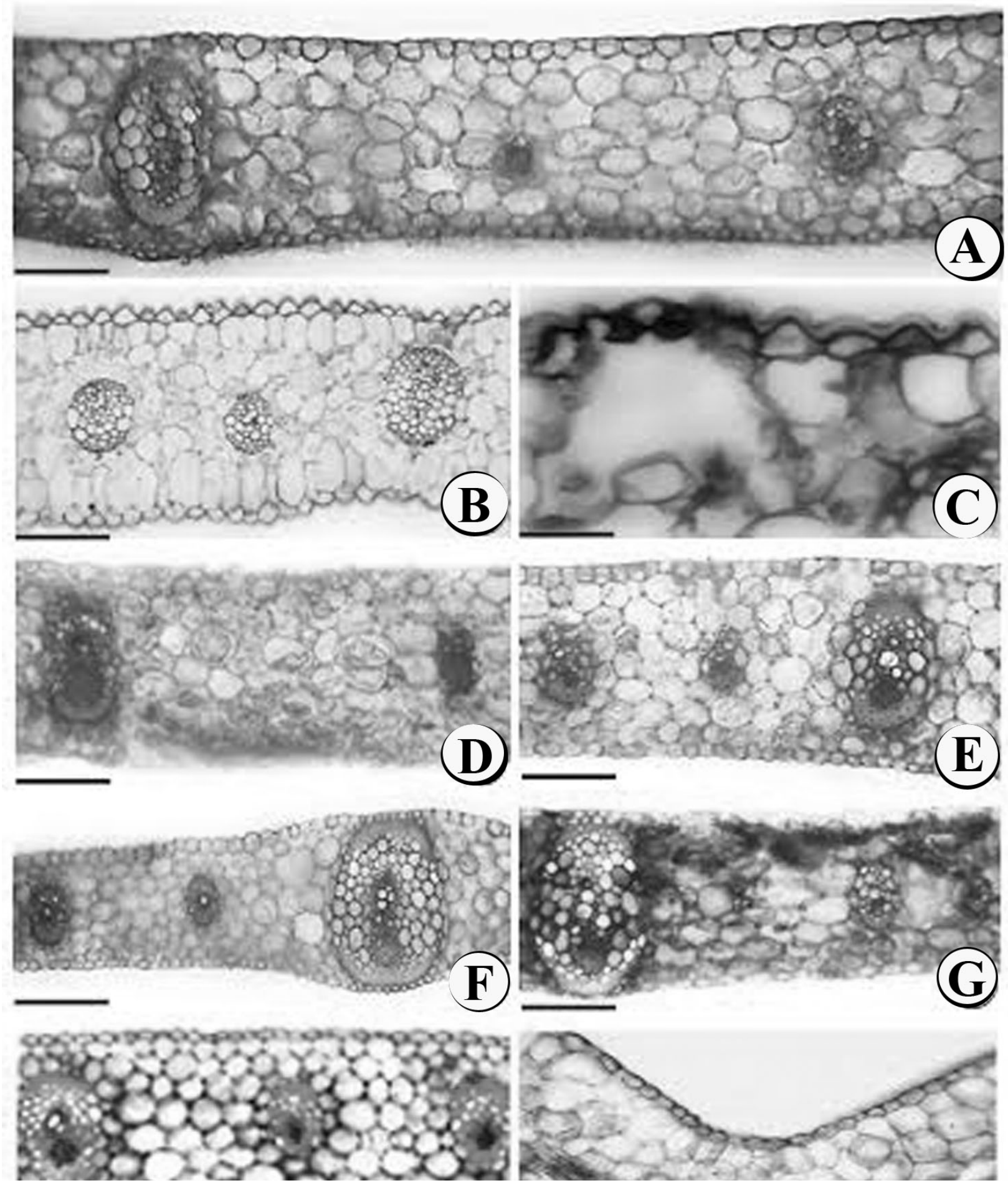

Figs 7A-G. Leaf cross-sections. A. Huntleya meleagris; B. Dichaea trulla; C. estomata of Dichaea trulla in superior position; D. Promenaea rollisonii; E. Paradisanthus micranthus; F. Zygopetalum maxillarie; G. Zygopetalum pedicellatum; H. Koellensteinia tricolor; I. Warczewiczella wailesiana. Bars: Figs. A, B; D-I $=100 \mu \mathrm{m} ;$ Fig. C $=50 \mu \mathrm{m}$.

As in others Zygopetalinae (Stern et al. 2004), raphides are common in the cortex of the aerial stems and rhizomes. Flavonoidics crystals were found in the rhizomes of $D$. trulla, Huntleya meleagris, K. tricolor, P. micranthus, Promenaea xanthina and Warczewiczella wailesiana (Tab. 3). Starch grains are common in the rhizomes and aerial stems, as reported for other Orchidaceae (Rosso 1966, Scatena \&Nunes 1996).

All pseudobulbs are similar in organization, with a onelayered epidermis devoid of trichomes and stomata and covered by a thickened cuticle. The epidermal cell walls are, in general, straight and narrow, except for Zygopetalum 


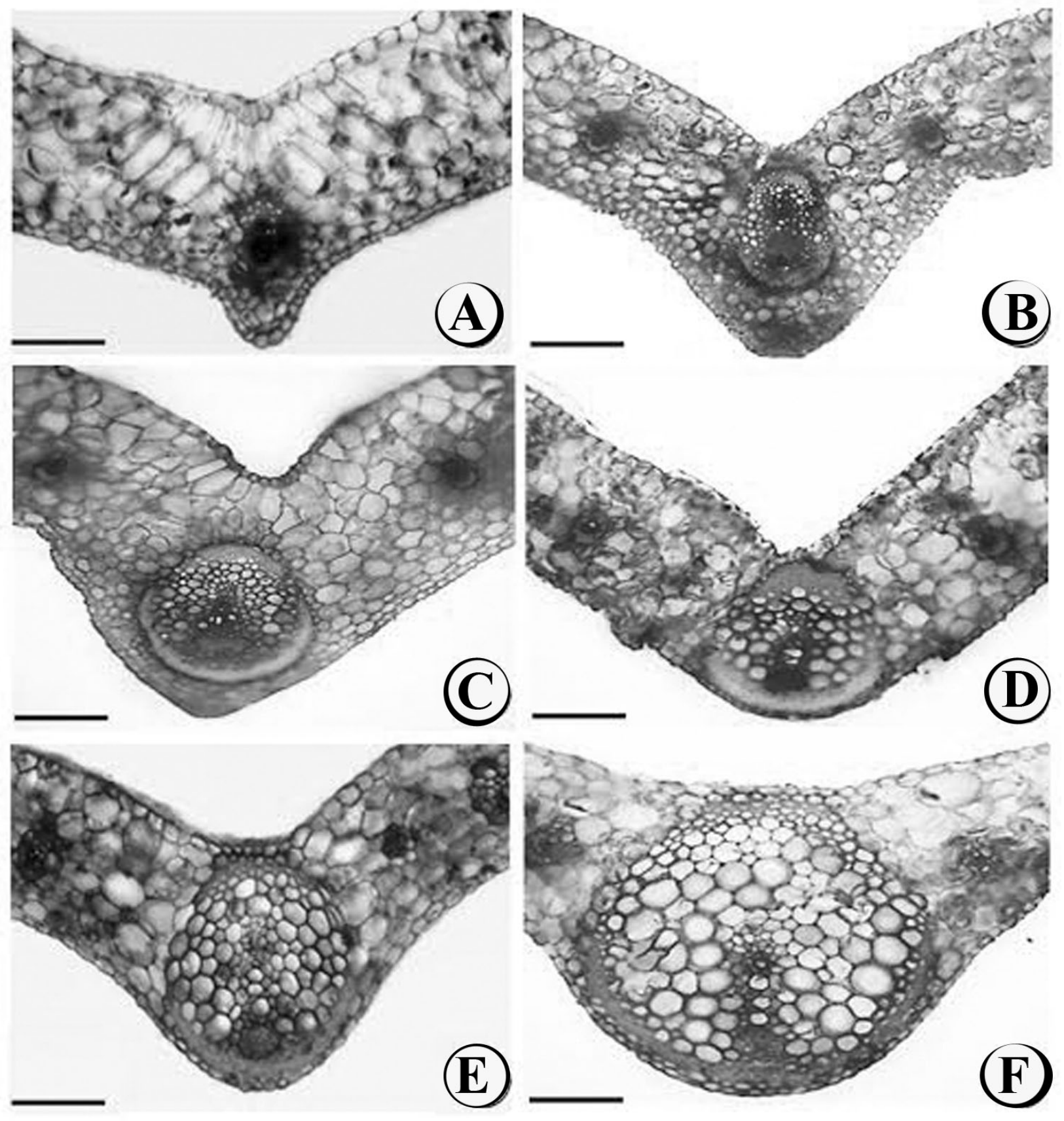

Figs. 8A-F. Leaf cross-sections showing central vascular bundles. A. Promenaea rollisonii; B. Promenaea xanthine; C. Huntleya meleagris; D. Zygopetalum mackayi; E. Zygopetalum pedicellatum; F. Zygopetalum maxillarie. Bars: Figs. 8A-F $=100 \mu \mathrm{m}$.

mackayi with waved thickened walls, as observed for Eria braccata from the Epidendroideae subfamily (Khasim Mohana \& Rao 1990). Internally there is a parenchymatic tissue with scattered vascular bundles protected by layers of sclerified cells adjacent to the phloem (smaller bundles) and to the xylem and phloem (larger bundles). Like in the aerial stems and rhizomes, there is not a defined limit between the cortex and the central cylinder and in all pseudobulbs there is a higher concentration of smaller bundles near the organ surface (Fig. 5). This arrangement coincides with that described for the pseudobulbs of other Zygopetalinae (Stern et al. 2004).

The parenchymatous region possesses large and small cells which commonly contain starch, confirming the storage function of the organs (Haberlandt 1914, Pridgeon 1986, Stern \& Morris 1992). The large cells may or may not possess secondary thickened walls and are like the water storage cells found in leaves and pseudobulbs of the African epiphytic orchids. These cells are named tracheoid elements (Olatunji \& Nengim 1980). Pridgeon (1982) 
Table 6. Environment, habit and anatomical traits of Zygopetalinae genres analyzed in this study and the Stern et al. (2004). $+=$ presence; - = absent, $\mathrm{ct}=$ cuticle thickness $(\mu \mathrm{m})$; ae = abaxial stomata with protected pore; $\mathrm{cs}=$ group of cells sclerified; wsc = water storage cells; hyp = hypodermis; steg $=$ sstegmata; $\mathrm{n} / \mathrm{a}=$ not analyzed. $1=$ absent in Promenaea rollisonii $; 2=$ presence only in Zygopetalum pedicellatum; $3=$ absent in Promenaea xanthina; $=$ there are no references as to character analysis.

\begin{tabular}{|c|c|c|c|c|c|c|c|c|c|}
\hline \multirow{3}{*}{ Genus } & \multicolumn{4}{|c|}{ Water storage features } & \multicolumn{5}{|c|}{ Resistance to desiccation features } \\
\hline & \multirow[b]{2}{*}{ Epidermis } & \multicolumn{3}{|c|}{ Mesophyll } & \multicolumn{2}{|c|}{ Epidermis } & \multicolumn{2}{|c|}{ Mesophyll } & \multirow{2}{*}{$\frac{\underline{\text { Fibers }}}{\text { Pericyclics }}$} \\
\hline & & $\begin{array}{l}\text { Number of } \\
\text { layers }\end{array}$ & Нyp & wsc & ct $(\mu \mathrm{m})$ & ae & cs & steg & \\
\hline \multicolumn{10}{|c|}{ This study } \\
\hline Dichaea & - & 5 & + & + & $7-12$ & + & - & + & + \\
\hline Hoeneella & - & 8 & + & + & $3-6$ & + & - & + & + \\
\hline Huntleya & - & 10 & + & + & $3-6$ & + & - & + & + \\
\hline Koellensteinia & - & 5 & - & + & $3-6$ & + & - & + & + \\
\hline Paradisanthus & - & 8 & - & + & $3-6$ & + & + & + & + \\
\hline Promenaea & - & 5 & $+/-^{1}$ & + & $3-6$ & + & + & + & + \\
\hline Warczewiczella & - & 12 & - & + & $7-12$ & + & - & + & + \\
\hline Zygopetalum & - & 6 & - & + & $7-12$ & + & $++^{2} /-$ & + & + \\
\hline \multicolumn{10}{|c|}{ Stern et al. (2004) } \\
\hline Dichaea & - & 5 & + & + & $7-7,5$ & + & - & + & + \\
\hline Hoeneella & $\mathrm{n} / \mathrm{a}$ & $\mathrm{n} / \mathrm{a}$ & $\mathrm{n} / \mathrm{a}$ & $\mathrm{n} / \mathrm{a}$ & $\mathrm{n} / \mathrm{a}$ & $\mathrm{n} / \mathrm{a}$ & $\mathrm{n} / \mathrm{a}$ & $\mathrm{n} / \mathrm{a}$ & $\mathrm{n} / \mathrm{a}$ \\
\hline Huntleya & - & 10 & + & + & $7-7,5$ & + & - & + & + \\
\hline Koellensteinia & - & 5 & + & + & $5-6$ & + & - & + & + \\
\hline Paradisanthus & - & 8 & + & $?$ & $3-5$ & + & - & + & + \\
\hline Promenaea & - & 6 & + & + & $3-5$ & + & - & $+/-^{3}$ & + \\
\hline Warczewiczella & $\mathrm{n} / \mathrm{a}$ & $\mathrm{n} / \mathrm{a}$ & $\mathrm{n} / \mathrm{a}$ & $\mathrm{n} / \mathrm{a}$ & $\mathrm{n} / \mathrm{a}$ & $\mathrm{n} / \mathrm{a}$ & $\mathrm{n} / \mathrm{a}$ & $\mathrm{n} / \mathrm{a}$ & $\mathrm{n} / \mathrm{a}$ \\
\hline Zygopetalum & - & 6 & + & + & $5-7,5$ & + & - & + & + \\
\hline
\end{tabular}

refers to these cells as "idioblasts with spiral thickening" and describes its presence in the leaf hypodermis and mesophyll of certain Pleurothallidinae.

Comparing the pseudobulbs with the rhizomes, the first possess a smaller amount of collateral vascular bundles. Withner et al. (1974) observed that the rhizomes contain about four times more vascular bundles them the pseudobulbs and interpreted this feature as a reason for the woody appearance of rhizomes, compared to the relative softness of the pseudobulbs.

\section{Leaves}

Like most of Zygopetalinae studied by Stern et al. (2004), the leaves are hypostomatic and possess a mesophyll of a few cell layers not differentiated into palisade and spongy parenchyma (Figs. 7-8). The epidermis is onelayered and is covered by a cuticle of variable thickness (3-6 to 7-12 micrometers). The cuticle thickness was used as a taxonomic character by Rosso (1966) who recognized within the Cypripedioideae (Orchidaceae) genera with plicate leaves and thin cuticle and genera with conduplicated leaves and thick cuticle. However, the cuticle thickness seems to be determined by the degree of sun exposure, as leaves exposed to intense solar radiation tend to display a thicker cuticle on both sides (Withner et al.1974). In the case of the species studied here there seems not to be a direct relationship between cuticle thickness and the environment occupied by plants. For example, in the two species of Promenaea, which are typical of shady places and grow as epiphytes on lower stems, the leaves are covered by a cuticle of the same thickness as in Koellensteinia tricolor, a species characteristic of open areas such as rock fields. Likewise, the leaves of Zygopetalum mackayi, which lives in open countryside possess cuticle of similar thickness to that of Zygopetalum maxillare, which grows primarily in shaded environments inside forests.

In all leaves, the stomata occupy the same level of the epidermal cells or are slightly projected. The stomatal guard cells are thickened walled and possess a small cuticular projections forming a supra-stomatal chamber, as in other Zygopetalinae (Stern et al.2004). Supra-stomatal chambers, that keep a small compartment of moist air reducing the leaf transpiration, are common in epiphytic orchids living under high temperatures and low water availability (Bonates 1993, Rasmussen 1987), as many the species studied here.

Although not reported for any Zygopetalinae investigated by Stern et al. (2004), we observed in some representatives the occurrence of an adaxial hypodermis of large cells without chlorophyll, as described for other Orchidaceae (Ayensu \& Williams 1972, Mohana Rao \&Khasim 1987, Pridgeon \& Williams 1979, Pridgeon \& Stern 1982, Khasim \& Mohana Rao 1990), including some Zygopetalinae (Oliveira \& Sajo 1999b). This layer, interpreted as a structure for water 
storage, seems to be frequent in epiphytic representatives appearing in Gesneriaceae, Ericaceae, Clusiacea, Araliaceae and epiphytic bromeliads (Madison 1977). According to Haberlandt (1914) and Madison (1977), besides storing water, the hypodermis helps to avoid heating, especially in the epiphytic plants with Crassulacean acid metabolism (CAM).

In the mesophyll of all species there are some water storage cells like those described by Stern et al. (2004) (Tab. 6) suggesting that this feature is widespread amongst the Zygopetalinae.

In general, the species studied here possess anatomical features that can be interpreted as adaptations to drought, a situation that typically prevails in epiphytic environments where most of them live. Besides the occurrence of a velamen, which protects the root from heating and the subsequent loss of water (Pridgeon 1987) the leaves of all species are hypostomatic and possess stomata protected by cuticular projections, which are considered to reduce the rate of water loss (Rasmussen 1987, Bonates 1993). In the leaves there are also water storage cells and the vascular bundles are surrounded by fibers, which provide mechanical support during extreme dehydration. In some representatives, the leaves also possess a hypodermal layer to store water and/or groups of fibers not related to the vascular bundles (Tab. 5), which increase mechanical support during dehydrating periods. Moreover, several species possess pseudobulbs (Tab. 3), an enlarged stem axis which stores water and nutrients (Betchel et al.1981).

Adjacent to the vascular bundles sclerified cells with silica bodies (the stegmata) appear in all organs, being more frequent in the pseudobulbs (Tab. 3). Although the role of the silica is not yet well established, stegmata are common in xerophytic, epiphytic orchids, and absent in terrestrial mesophytic orchids, indicating some relationship between xerophytism and silica (Møller \& Rasmussen 1984). Also, the presence of flavonoid compounds in most of species (Tabs. 3, 5), may be related to their resistance/tolerance to possible water stress, since they are associated with the free radicals commonly produced in plants subjected to environmental pressures (Yamasaki et al.1997). On the other hand, some features, such as the number of velamen, root cortex and mesophyll layers can be useful in the systematic analysis of determined taxa specially Dichaea, Promenaea and Zygopetalum.

\section{ACKNOWLEDEGMENTS}

We thank Prof. Edwin Taylor for the English revision of the manuscript and an anonymous referee for the useful comments. MG Sajo thanks Conselho Nacional de Desenvolvimento Científico e Tecnológico (CNPq) for the fellowship.

\section{REFERENCES}

Arditti, J. 1967. Factors affecting the germination of orchid seeds. Botanical Review 33:1-95.
Ayensu,E.S. \& Williams, N.H. 1972. Leaf anatomy of Palumbina and Odontoglossum, subgenus Osmoglossum. American Orchid Society Bulletim 41:687-696.

Barros,F. de.1990. Diversidade taxonômica e distribuição geográfica das Orchidaceae brasileiras. Acta Botanica Brasilica 4:177-187.

Benzing, D.H., Friedman, W.E., Peterson,G. \& Renfrow. A. 1983. Shootlessness, velamentous roots, and the pre-eminence of Orchidaceae in the epiphytic biotope. American Journal of Botany 70:121-133.

Betchel,H., Cribb, P. \& Launert, E. 1981. The manual of cultivated orchid species. The MIT Press, Cambridge. 444 p.

Bonates, L. C. M. 1993. Estudos ecofisiológicos de Orchidaceae da Amazônia II. Anatomia ecológica foliar de espécies com metabolismo CAM de uma campina da Amazônia central. Acta Amazonica 23:315-348.

Braga,P. I. S. 1977. Aspectos ecofisiológicos de Orchidaceae da Amazônia II. Anatomia ecológica foliar de espécies com metabolismo CAM de uma campina da Amazônia central. Acta Amazonica 7:1-89.

. Braga, P. I. S. 1987. Orquídeas. Biologia floral. Ciência Hoje 5:53-55.

Bücherl, W. 1962. Técnica Microscópica. Polígono, São Paulo. 171 p.

Bukatsh,F. 1972. Benerkemgem zeir doppelfarbeing astrablau-safranina. Mikrokosmos 61:255-256.

Campos, F. A. D. B. 2008. Considerações sobre a Família Orquidacea: taxonomia, antropismo, valor econômico e tecnologia. O mundo da saúde 32:383-392.

Chase, M., Freudenstein, J. F. \& Cameron, K. M. 2003. DNA data and Orchidaceae systematics In A new phylogenic classification (K. W. Dixon, S. P., Kell, R. L. Barrett \& P. J. Cribb), Orchid conservation, Natural History Publications, Kota Kinabalu, Sabah, p. 69-89.

Claus, E. P. 1954. A study of the root system of Hemerocallis fulva L. I. Morphology and histology. Journal of American Pharmacology Association 43:188.

Costa, A. F. 1982. Farmacognosia. Fundação Calouste Gulbenkian, Lisboa. 1032 p.

Dahlgren, R. M. T., Clifford, H.T. \& Yeo, P. F. 1985. The families of the Monocotyledons: structure, evolution and taxonomy. SpringerVerlag, Berlin. 520 p.

Dahlgren, R. M. T. \& Clifford, H. T. 1982. The Monocotyledons: A Comparative Study. Academic Press, London. 378 p.

Dressler, R. L. 1981.The Orchids: natural history and classification. Harvard University Press, Cambridge. 258 p.

Dressler, R. L. 1993. Phylogeny and classification of the orchid family. Dioscorides Press, Portland. 314 p.

Dressler, R. L. 2005. How many orchid species? Selbyana 26:155-158.

Dressler, R. L. \& Chase, M. W.1995. Whence the orchids? In Monocotyledons: systematics and evolution (P. Rudall, P. Cribb, D. Cutler, \& C. Humphries, (Eds) Royal Botanic Gardens, Kew, UK, p. 217-226.

Dycus, A. M. \& Knudson,L. 1957. The role of the velamen of the aerial roots of orchids. Botanical Gazette 119:78-87.

Engard, C. J. 1944. Morphological identity of the velamen and exodermis in orchid. Botanical Gazette 105:457-462.

Gonzaga, M. E. B. \& Gonzaga, A. L. A. 1996. Estrutura das orquídeas. Boletim Catarinense de Orquídeas e Bromélias 4:2-3.

Haberlandt, G. F. J. 1914. Physiological plant anatomy. Macmillan \& Co, London. 614 p.

Holttum, R. 1955. Growth habitats of monocotyledons: variations on a theme. Phytomorphology 5:399-413.

Jansen, W. A. 1962. Botanical histochemistry. H.H. Freeman \& Co, San Francisco. 408 p.

Johansen, D. A. 1940. Plant microtechnique. Mc Graw Hill, New York. 790 p.

Khasim, S. M. \&Mohana Rao, P. R.1990.Anatomy in relation to taxonomy in some members of Epidendroideae (Orchidaceae). Phytomorphology 40:243-250.

Kurzweil,H., Linder, H.P., Stern, W.L. \& Pridgeon, A. M.1995. Comparative vegetative anatomy and classification of Diseae (Orchidaceae). Botanical Journal of Linnean Society 117:171-220.

Madison, M.1977. Vascular epiphytes: their systematic occurrence and salient features. Selbyana 2: 1-13.

Mauseth, J. D. 2009. Botany: an introduction to plant biology. Jones \& Bartlett, Burlington. 696 p. 
Metcalfe, C. R. 1963. Comparative anatomy as a modern Botanical discipline. In Advances in botanical research (R. D. Preston), v. VI. Academic Press, New York, p. 101-147.

Mohana Rao, P. R. \& Khasim, S. M. 1987. Anatomy of three species of Bulbophyllum (Orchidaceae) with comments on their ecological adaptability and taxonomy. P Indian AS-Plant Science 97:391-397.

M $\theta 11$ r, J. D., Rasmussen, H. 1984. Stegmata in Orchidales character state distribution and polarity. Botanical Journal of Linnean Society 89:53-76.

Olatunji, O. A. \& Nengim, R. O. 1980. Occurrence and distribution of tracheoidal elements in the Orchidaceae. Botanical Journal of Linnean Society 80:357-370.

Oliveira, V. C. \& Sajo, M. G. 1999a.Root anatomy of nine Orchidaceae species. Brazilian Archives of Biology and Technology 42:405-413.

Oliveira, V. C. \& Sajo, M. G. 1999b. Anatomia foliar de espécies epífitas de orquídeas. Brazilian Journal of Botany 22:365-374.

Pinheiro, F., Barros, F. de \& Lourenço, R. A. 2004. O que é uma orquídea. In Orquidologia sul-americana: uma compilação científica (F. Barros de \& G. B. Kerbauy). Secretaria do Meio Ambiente, São Paulo, p. 11-33.

Porembski, S. \& Barthlott,W. 1988. Velamen radicum micromorphology and classification of Orchidaceae. Nordic Journal of Botany 8:117137.

Pridgeon,A. M. 1982. Diagnostic anatomical characters in the Pleurothallidinae (Orchidaceae). American Journal of Botany 69:921-938.

Pridgeon, A. M. 1986. Anatomical adaptations in Orchidaceae. Lindleyana 1:90-101.

1987. The velamem and exodermis of orchid roots. In Orchid biology: reviews and perspectives. (J. Arditti). Cornell University Press, Ithaca, p. 30-56.

Pridgeon, A. M. \& Stern, W. L. 1982. Vegetative anatomy of Myoxanthus (Orchidaceae). Selbyana 7:55-63.

Pridgeon, A. M. \& Williams, N. H. 1979. Anatomical aspects of Dresslerella (Orchidaceae). Selbyana 5:120-134.

Pridgeon, A. M., Cribb, P. J., Chase, M.W. \& Rassmussen, F. N. 2009. Genera Orchidacearum, v. 5: Epidendroideae (part two). Oxford University Press, Oxford. 696 p.

Prychid, C.J. \& Rudall, P. J. 1999. Calcium Oxalate Crystals in Monocotyledons: A Review of their Structure and Systematics. Annals of Botany 84:725-739.

Rao, A. N. 1977. Tissue culture in the orchid industry. In Plant Cell, Tissue and Organ Culture. J. Reinert, \& Y. P. S. Bajaj). Kluwer Academic, New York, p.44-69.

Rasmussen, H. 1987. Orchid stomata-structure, differentiation, function and phylogeny. In Orchid Biology: reviews and perspectives (J. Arditti ed.), v. IV. Cornell University Press, Ithaca, p. 105-138.

Rosso, S. W. 1966. The vegetative anatomy of the Cypripedioideae (Orchidaceae). Journal of Linnean Society Botany 59:309-341.
Ruschi, A. 1997. Orquídeas do Estado do Espírito Santo. Expressão e Cultura, Rio de Janeiro. 96 p.

Rütter, B.E. \& Stern, W. L. 1992.An assessment of quantitative features of velamen stratification and protoxylem strands in roots of Orchidaceae. Lindleyana 9:219-225.

Sanford, W. W. 1974. The ecology of orchids. In The orchids: scientific studies (C. L Withner ed.). John Wiley \& Sons, New York, p.1-100.

Sanford,W.W. \& Adanlawo, I. 1973. Velamen and exodermis characters of West African epiphytic orchids in relation to taxonomic grouping and habitat tolerance. Botanical Journal of Linnean Society 66:307321.

Scatena, V. L. \& Nunes, A. C. 1996. Anatomia de Pleurothallis rupestris Lindl. (Orchidaceae) dos campos rupestres. Boletim de Botânica da Universidade de São Paulo 15:35-43.

Schultz, A. R. 1991. Introdução ao estudo da botânica sistemática. 6th ed. Sagra, Porto Alegre. 294 p.

Senghas, K. \& Dietrich, H. 1992. Tribus Maxillarieae. In Die Orchideen (R. Schlechter ed.), v. 1/B. Paul Parey, Berlin, p. 1617-1620.

Shushan, S. 1974. Orchids. In The orchids: scientific studies (C. L. Withner ed.). John Wiley \& Sons, New York, p. 45-72.

Singh, H. 1986. Anatomy of roots in some Orchidaceae. Acta Botanica Brasilica 14:24-32.

Soltis, D. E., Soltis, P. E., Endress, P. K. \& Chase, M. W. 2005. Phylogeny and evolution of Angiosperms, Sinauer Associates, Sunderland. 740 p.

Souza, V. C. \& Lorenzi, H. 2012. Botânica Sistemática. Instituto Plantarum, Nova Odessa. 768 p.

Stern, W. L. \& Morris, M. W. 1992. Vegetative anatomy of Stanhopea (Orchidaceae) with special reference to pseudobulb water-storage cells. Lindleyana 7:34-53.

Stern, W. L., Morris, M.W. \& Judd, W. S. 1993. Comparative vegetative anatomy and systematics of Spiranthoideae (Orchidaceae). BotanicalJournal of Linnean Society 113:162-197.

Stern, W. L., Judd, W. S. \& Carlsward, B. S. 2004. Systematic and comparative anatomy of Maxillareae (Orchidaceae), sans Oncidiinae. Botanical Journal of Linnean Society 144:251-274.

Szlachetko, D. 1995. Systema Orchidalium. Fragmenta Floristica e Geobotanica, supplementeum 3. W. Szafer Institute, Kraków. 152 p.

Whitten, W. M., Williams, N. H., Dressler, R.L., Gerlach, G., Pupulin, F. 2005. Generic relationships of Zygopetalinae (Orchidaceae: Cymbidieae): combined molecular evidence. Lankesteriana 5:87-107.

Williams N. H. 1979. Subsidiary Cells in the Orchidaceae: Their General Distribution with Special Reference to Development in the Oncidieae. Botanical Journal of the Linnean Society 78: 41-66.

Withner, C. L., Nelson, P. K. \& Wejksnora, P. J. 1974. The anatomy of orchids. In The orchids: scientif studies (C. L Withner ed.). John Wiley \& Sons, New York, p. 267-334.

Yamasaki, H., Sakihama, Y. \& Ikehara, N. 1997. Flavonoid-peroxidase reaction as detoxification mechanism of plant cell against $\mathrm{H}_{2} \mathrm{O}_{2}$. Plant Physiology 19:481-486. 